\title{
Analysis of Compression Strength on Plastic Brick Material
}

\author{
Mislina $^{1, *}$, Devendra Aulianur ${ }^{2}$, Anhar $^{3}$ \\ ${ }^{1,3}$ Industrial Engineering Study Program, Aceh Selatan Polytechnic, Aceh Selatan, 23711, Indonesia \\ ${ }^{2}$ Student of Industrial Engineering Study Program, Aceh Selatan Polytechnic, Aceh Selatan, 23711,Indonesia \\ ummialif123@gmail.com ${ }^{1}$ *; aulia.alfarisy@gmail.com ${ }^{2}{ }^{3}$ shopcorner87@gmail.com
}

ARTICLE INFO

ABSTRACT

Article history:

Accepted

Keyword:

Waste

Stone brick

Plastic brick

Waste treatment
Plastic waste has a negative impact on the environment, handling plastic waste by utilizing plastic waste and sand to make plastic bricks. This study aims to make plastic bricks, test the compressive strength of plastic bricks and determine the density. Making plastic stones using the experimental method, this method of experimenting with experience to prove themselves a statement that is learned. Maximum compressive strength test results in samples $1,1 \mathrm{~kg}$ of plastic: $1 \mathrm{~kg}$ of sand $=141.42 \mathrm{~kg} / \mathrm{cm}^{2}$. Sample $2,1.15 \mathrm{~kg}$ plastic: $0.85 \mathrm{~kg}$ sand $=117.23 \mathrm{~kg} / \mathrm{cm} 2$ and Sample $3,0.85 \mathrm{~kg}$ plastic: 1.15 $\mathrm{kg}$ sand $=112.50 \mathrm{~kg} / \mathrm{cm} 2$. Average mass weight sample $1(1.25 \mathrm{~kg})$ and the average lost weight of sample $1(0.75 \mathrm{~kg})$, average weight mass of sample $2(1.39 \mathrm{~kg})$ and lost average sample weight $2(0.61$ $\mathrm{kg})$, mass average weight of sample $3(1.3 \mathrm{~kg})$ and loss of average sample weight $3(0.7 \mathrm{~kg})$ with total material used $2 \mathrm{~kg}$. Based on the results of compressive strength tests, plastic bricks meet quality standards (SNI 15-2-94-1991). Thus this research can replace industrial products and maintain a healthy environment.

Copyright (C) 2019 Politeknik Aceh Selatan. All rights reserved.

\section{Introduction}

In everyday life, society cannot be separated from the world of plastic. Most products use plastic as packaging or as a basic material, as a result the number of plastic products that will become trash continues to grow. Each year plastic waste shows a significant increase.

Along with technological developments, industry and population are pushing for increased use of plastics in Indonesia. The advantages of plastic in terms of use encourage people to use plastic in their lives. The increasing use of equipment from plastic materials causes more plastic waste to be produced. Plastic waste has a negative impact on the environment because it cannot decompose quickly and can reduce soil fertility. Plastic waste that is discarded carelessly can also clog sewers and rivers that can cause flooding.

The way to handle plastic waste developed in this research is to convert plastic waste into building materials. This method is actually included in the recycle process. In this way two important problems can be overcome, namely the dangers of accumulating plastic waste which can cause environmental damage and obtaining building materials from recycled plastic waste that has value thus increasing the community economy [1].

\section{DASAR TEORI}

\section{A. Batu Bata}

Brick is one of the building elements in the construction of buildings made of clay plus water with or without other mixed materials through several stages of work, such as digging, processing, printing, drying, burning at high temperatures to ripen and change color, and will harden like a rock if it is cooled so that it cannot be crushed again when immersed in water [2][3]. The brick quality requirements are in accordance with the standards (SNI 15-2094-1991) as follows: 
Table 1. Strength of stone brick

\begin{tabular}{|l|c|c|}
\hline \multirow{2}{*}{ Quality of Bricks } & \multicolumn{2}{|c|}{ Average Compressive Strength } \\
\cline { 2 - 3 } & $\mathrm{Kg} / \mathrm{cm}^{2}$ & $\mathrm{~N} / \mathrm{mm}^{2}$ \\
\hline Level 1 & More than 100 & $>10$ \\
\hline Level 2 & $80-100$ & $8-10$ \\
\hline Level 3 & $60-80$ & $6-8$ \\
\hline
\end{tabular}

B. Plastic

The plastic used is PET type plastic. The raw material for making plastics is oil and gas as natural sources. In its development, oil and gas have begun to be replaced by synthetic materials so that the desired plastic properties can be obtained by copolymerization, lamination, and extrusion [4].

\section{Sand}

According to regarding the definition of sand which is a natural granular material that has not been consolidated. Chemical element of silica sand ( $\mathrm{SiO} 2)$, Sand consists of granules measuring from 1/16-2 mm. Granular material that is finer than sand is called silt, and the larger one is called gravel [5].

\section{Compressive strength}

Based on SNI 1974: 2011, compressive strength is calculated by dividing the maximum compressive strength received by the test object during testing by cross-sectional area. This test is carried out using a Digital Compression Machine to obtain the compressive strength of the test object. Testing is done when the sample age 3 days [6]. To find the compressive strength using the following formula:

\section{$\underline{\operatorname{Load}(\mathrm{kN}) \times 101,9}$}

Cross-sectional area

\section{Method}

A. Experiment Design

In this manufacturing experiment we made 3 samples with 9 specimens with different compositions in each sample such as the following table 2 .

Table 2. Composition of Materials Used

\begin{tabular}{|l|l|c|c|c|c|}
\hline \multirow{2}{*}{ No } & \multirow{2}{*}{ Materials } & \multirow{2}{*}{ Unit } & \multicolumn{3}{c|}{ Composition } \\
\cline { 4 - 6 } & & & Sample 1 & Sample 2 & Sample 3 \\
\hline 1 & Waste plastic bottles & $\mathrm{Kg}$ & 1 & 1,15 & 0,85 \\
\hline 2 & Sand & $\mathrm{Kg}$ & 1 & 0,85 & 1,15 \\
\hline 3 & Water & Liter & Sufficiently & Sufficiently & Sufficiently \\
\hline 4 & Lubricant & Liter & Sufficiently & Sufficiently & Sufficiently \\
\hline 5 & Firewood & $\mathrm{Kg}$ & Sufficiently & Sufficiently & Sufficiently \\
\hline
\end{tabular}

In making this plastic brick the method used is the experimental method. This method is a method of conducting an experiment by experiencing to prove itself a statement being studied, this method of doing an experiment about something, observing the process and writing down the results of the experiment.

\section{B. Test Equipment}

The equipment used in this study are as follows: 
Table 3. Equipment

\begin{tabular}{lll}
\hline No & \multicolumn{1}{c}{ Equipment } & Amount \\
\hline 1 & Pan & 1 Unit \\
2 & Stirring Spoon & 1 Unit \\
3 & Iron mold & 1 Unit \\
4 & Hammer & 1 Unit \\
5 & Bucket & 1 Unit \\
6 & Balance & 1 Unit \\
\hline
\end{tabular}

\section{C. $\quad$ Procedure}

In general, the work procedures for making plastic bricks can be described as follows:

1. Preparing tools and materials

Prepare tools and materials to facilitate the manufacturing process (as in table 2 . composition of materials used and table 3. equipment).

2. The Smelting Process

Melt the plastic waste in the pan until it melts, to melt it takes 3 hours.

3. Mixing Process

After the plastic waste has melted, mix the sand with the liquid plastic waste stirring with a stirring spoon until evenly distributed.

4. Printing Process

- Polishing the lubricant into an iron mold so that it does not stick when opening the mold.

- Insert the mixture into an iron mold with dimensions $(24 \mathrm{~cm} \times 11.5 \mathrm{~cm} \times 5.2$ $\mathrm{cm})$ and hole diameter $(2 \mathrm{~cm})$.

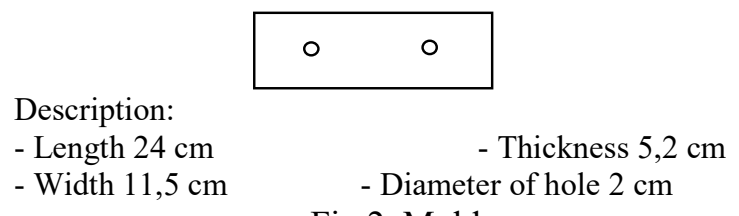

Fig 2. Mold

5. Compaction Process

Leave the plastic brick mixture in an iron mold and pound it with a hammer so that the compaction is evenly distributed.

6. Immersion Process

Put the iron mold containing the mixture that has been compacted into a water container for 10 minutes to quickly harden.

7. Release from the mold

Open the iron mold and leave the sample for 3 days in the sun so that the hardening is perfect.

8. Finishing

After the sample is 3 days old, the plastic brick sample is ready to be tested / used.

D. Working Procedure of Compressive Strength Test Machines

As for the instruction/procedure of test work with the Digital Compression Machine Test is as follows:

1. Before testing done, make sure the tools and surrounding environment are in clean condition.

2. Make sure the appliance is connected with power

3. Make sure the test objects are dry

4. Weigh weight and measure the dimensions of the test objects

5. For the cylinder object, the upper side (uneven) needs to be given layer capping according to the instruction of strong concrete press test

6. Place the test objects precisely perpendicular to the iron plate 
7. Make sure the machine door is closed

8. Specify and set the load type, sample type, no sample, and other provisions on the touchscreen machine.

9. Give the test object a load until the test object is destroyed by rotating the locking lever, when the field rarely press too far press the Quick Test button.

10. After the crushed test objects reopen the loading lever

11. Record load readings on the Compress machine dial

12. Remove test objects and clean the machine.

\section{Result}

\section{A. Product Results}

In this study, 2 products are as follows:

1. Specimen

Sample product is a product that is tested strong for the optimal results of the strong strength of plastic bricks Press test in concrete laboratory, civil Engineering, University of North Sumatra.
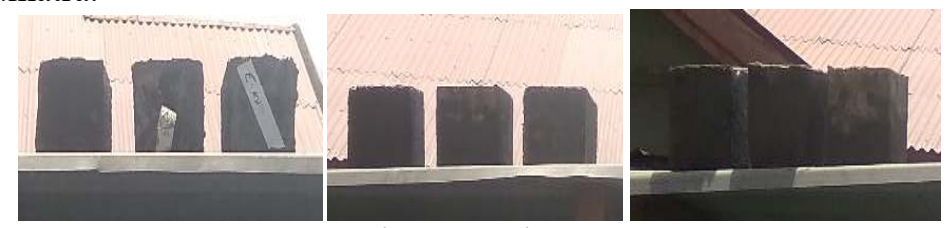

Fig 3. Specimen

2. Plastic Bricks Products

Plastic bricks products are products that will be applied with the dimensions $(24 \mathrm{~cm} \times 11$, $5 \mathrm{~cm} \times 5.2 \mathrm{~cm})$ and the hole diameter $(2 \mathrm{~cm})$.

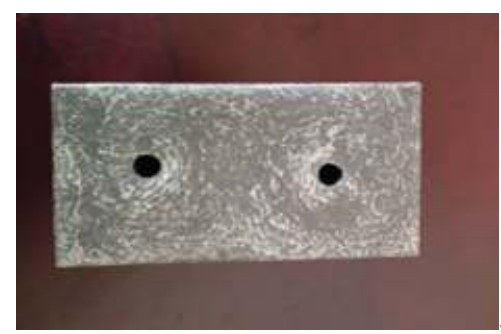

Gambar 4. Plastic brick

\section{B. Compression Strength Analysis}

Based on the results of strong test research of plastic brick press with material: plastic and sand waste with 3 samples of 9 test objects using the Digital Compression Machine tool as follows.

1. Sample 1

As for the strong test result press on Sample 1 can be seen in table 4.

Table 4. Result of compression test

\begin{tabular}{cccccc}
\hline No & Sample 1 & $\begin{array}{c}\text { Section Area } \\
\left(\mathrm{cm}^{2}\right)\end{array}$ & $\begin{array}{c}\text { Weight of } \\
\text { Specimens } \\
(\mathrm{Kg})\end{array}$ & $\begin{array}{c}\text { Load Press } \\
\text { Calibration } \\
(\mathrm{kN})\end{array}$ & $\begin{array}{c}\text { Sturdy press } \\
\text { during test } \\
\left(\mathrm{Kg} / \mathrm{cm}^{2}\right)\end{array}$ \\
\hline 1 & Specimen 1 & 100 & 1.210 & 84,4 & 86,04 \\
2 & Specimen 2 & 100 & 1.320 & 95,5 & 97,37 \\
3 & Specimen 3 & 100 & 1.230 & 138,7 & 141,42 \\
\hline
\end{tabular}


Strong test result Press on the sample 1 on the test objects 1 and 2 entered into the category of the plastic bricks Level 2 with a strong weight of $80-100 \mathrm{~kg} / \mathrm{cm} 2$, while the test objects 3 entered into the category of Level 1 with a strong weight greater than $100 \mathrm{~kg} / \mathrm{cm} 2$, (SNI 15-2094-1991). From the above results, here is a strong test research graph of press plastic bricks.

COMPRESSION TEST FOR SAMPLE 1

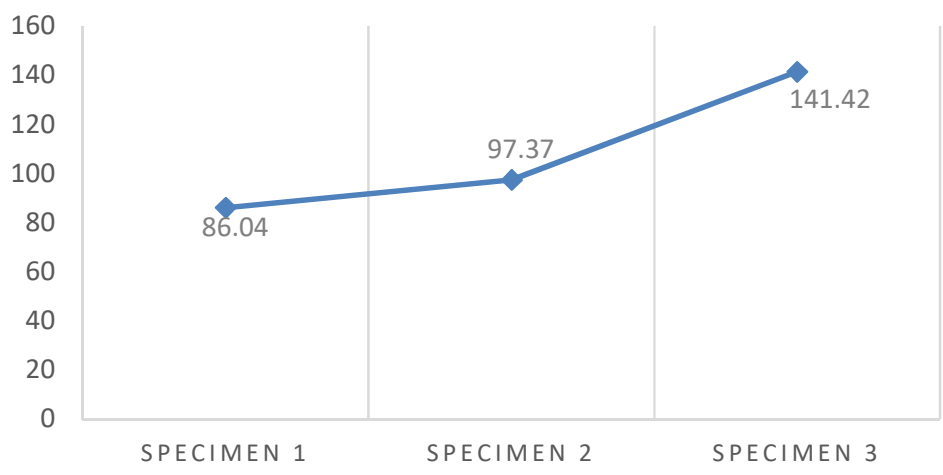

Fig 5. Chart of compression test for sample 1

2. Sample 2

As for the strong test result Press Sample 2 can be seen in table 5.

Table 5. Result of compression test

\begin{tabular}{cccccc}
\hline No & Sample & $\begin{array}{c}\text { Section Area } \\
\left(\mathrm{cm}^{2}\right)\end{array}$ & $\begin{array}{c}\text { Weight of } \\
\text { Specimens } \\
(\mathrm{Kg})\end{array}$ & $\begin{array}{c}\text { Load Press } \\
\text { Calibration } \\
(\mathrm{kN})\end{array}$ & $\begin{array}{c}\text { Sturdy press } \\
\text { during test } \\
\left(\mathrm{Kg} / \mathrm{cm}^{2}\right)\end{array}$ \\
\hline 1 & Specimen 1 & 100 & 1.420 & 87,5 & 99.84 \\
2 & Specimen 2 & 100 & 1.380 & 115,0 & 117,23 \\
3 & Specimen 3 & 100 & 1.370 & 26,6 & 27,38 \\
\hline
\end{tabular}

From the strong test result press above Sample 2 on the test object 1 entered into the category of the plastic bricks Level 2 with a strong weight $80-100 \mathrm{~kg} / \mathrm{cm} 2$ and the test object 2 entered into the category of level 1 with the strength greater than $100 \mathrm{~kg} / \mathrm{cm} 2$, while the test objects 3 Failed product that does not meet the strong force Test Press, (SNI 15-2094-1991). From the above results, here is a strong test research graph of press plastic bricks.

COMPRESSION TEST FOR SAMPLE 2

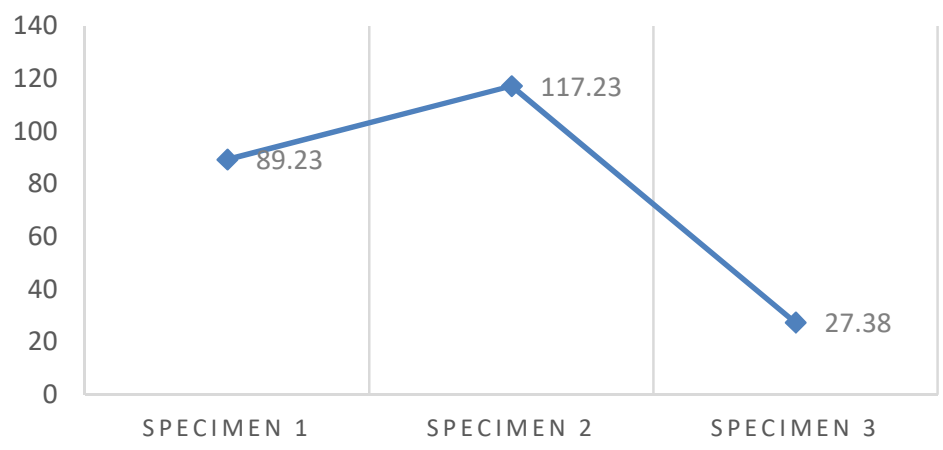

Fig 6. Chart of compression test for sample 2 


\section{Sample 3}

As for the strong test result Press sample 3 can be seen in Table 6 .

Table 6. Result of compression test

\begin{tabular}{cccccc}
\hline No & Sample & $\begin{array}{c}\text { Section Area } \\
\left(\mathrm{cm}^{2}\right)\end{array}$ & $\begin{array}{c}\text { Weight of } \\
\text { Specimens } \\
(\mathrm{Kg})\end{array}$ & $\begin{array}{c}\text { Load Press } \\
\text { Calibration } \\
(\mathrm{kN})\end{array}$ & $\begin{array}{c}\text { Sturdy press } \\
\text { during test } \\
\left(\mathrm{Kg} / \mathrm{cm}^{2}\right)\end{array}$ \\
\hline 1 & Specimen 1 & 100 & 1,380 & 110,3 & 112,50 \\
2 & Specimen 2 & 100 & 1,160 & 98,1 & 100,04 \\
3 & Specimen 3 & 100 & 1,360 & 73,6 & 75,03 \\
\hline
\end{tabular}

From the strong test result press over the sample 3 on the test object 1 entry into the category of plastic bricks Level 1 with a strong weight greater than $100 \mathrm{~kg} / \mathrm{cm} 2$ and 2 test objects enter the category of Level 2 with a strong weight $80-100 \mathrm{~kg} / \mathrm{cm} 2$, while the test objects 3 Enter into the category of level 3 with strong weight $60-80 \mathrm{~kg} / \mathrm{cm} 2$, (SNI 15-2094-1991). From the above results, the following strong test research graphs of press plastic bricks.

\section{COMPRESSION TEST FOR SAMPLE 3}

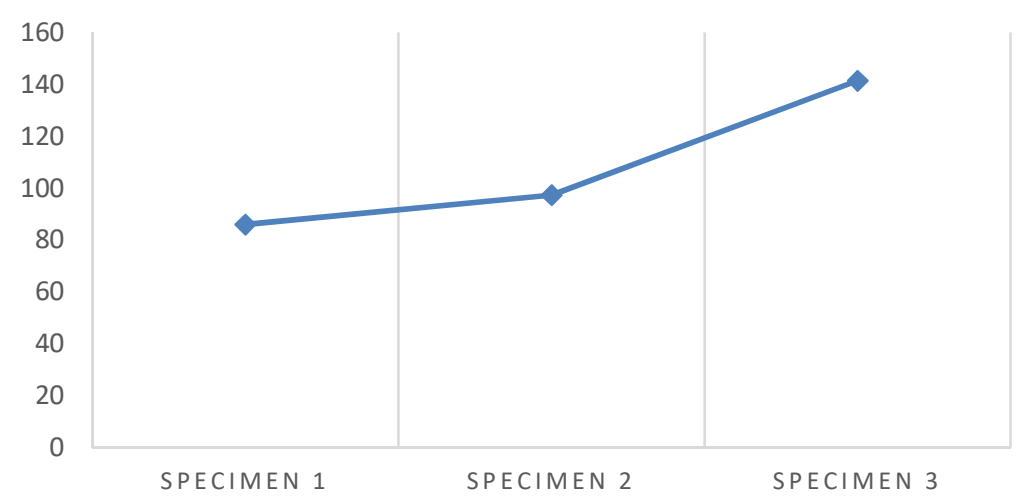

Fig 6. Chart of compression test for sample 3

\section{B. Discussion}

The average weight mass sample is $1(1.25 \mathrm{Kg})$ and the average loss of the sample weight is 1 $(0.75 \mathrm{Kg})$, the average weight mass of sample $2(1.39 \mathrm{Kg})$ and the average loss of sample weight 2 $(0.61 \mathrm{Kg})$, the average weight mass Sample $3(1.3 \mathrm{Kg})$ and the average loss of sample weight $3(0.7$ $\mathrm{Kg}$ ) with total ingredients used $2 \mathrm{Kg}$. Mass is necessary to know how much composition is wasted when the product is ready and compare the total amount required to make 1 plastic bricks product.

Based on the table and the chart of strong test results press above can be concluded that the plastic waste with the sand mixture produces a strong maximum press of $141.42 \mathrm{~kg} / \mathrm{cm} 2$. Strong value press plastic bricks highest obtained in Sample 1 with the concentration of plastic waste $1 \mathrm{Kg}$ and Sand $1 \mathrm{Kg}$.

Decreased test value strong press occurs in Sample 2 with plastic waste combination $1.15 \mathrm{Kg}$ and sand $0.85 \mathrm{Kg}$. Decrease in the strong press of plastic bricks as a result of the less maximization of passengers when printing and the use of lubricants with Too much to cause lubricating oil to enter the surface of the sample resulting in the material can not blend evenly so that the void of the room when printing and resulting in a porous sample. 


\section{Conclussion}

In this journal the author concluded some conclusion points as follows:

1. Strong maximum press occurs on the plastic waste $1 \mathrm{Kg}$ and Sand $1 \mathrm{Kg}$ can increase the test value of strong press with the result of strong press maximum of $141.42 \mathrm{Kg} / \mathrm{cm} 2$. Decrease of strong test value press on plastic waste $1.15 \mathrm{Kg}$ and sand $0.85 \mathrm{Kg}$ caused by the amount of lubricant too much, causing the cavity and also the process of reduction of the less maximum.

2. The average weight mass sample is $1(1.25 \mathrm{Kg})$ and the average loss of the sample weight is $1(0.75 \mathrm{Kg})$, the average weight mass of sample $2(1.39 \mathrm{Kg})$ and the average loss of sample weight $2(0.61 \mathrm{Kg})$, the average weight mass Sample $3(1.3 \mathrm{Kg})$ and the average loss of sample weight $3(0.7 \mathrm{Kg})$ with Total ingredients used $2 \mathrm{Kg}$. Mass is necessary to know how much composition is wasted when the product is ready and compare the total amount required to make 1 plastic bricks product.

\section{References}

[1] Purnomo, D. "Inovasi Batalastik sebagai Solusi Penanganan Sampah Plastik", SMA 1 Purwantoro, 2016.

[2] Huda, M dan Hastuti, E. "Pengaruh Temperatur Pembakaran dan Penambahan Abu Terhadap Kualitas Batu Bata," Fakultas Sains: Teknologi UIN Maliki Malang, 2012.

[3] N. Fitriadi and B. Syam, "The Investigation of Mechanical Behaviour of $\{$ OPEFB $\}$ Fibre Reinforced Foam Material Concrete to High Speed Impact Loads," \{IOP $\}$ Conf. Ser. Mater. Sci. Eng., vol. 536, p. 12011, Jun. 2019.

[4] Syarief, R., Santausa dan Isyana, "Teknologi Pengemasan Pangan", PAU Pangan dan Gizi. IPB: Bogor, 1989.

[5] Pettijohn, F. J., Potter, P. E. and Siever, R. "Sand and Sandstone," New York: SpringerVerlag, 1973.

[6] Malau, F, B. "Penelitian Kuat Tekan Dan Berat Jenis Mortar Untuk Dinding Panel Dengan Membandingkan Penggunaan Pasir Bangka Dan Pasir Baturaja Dengan Tambahan Foaming Agent Dan Silica Fum,”. Jurusan Teknik Sipil, Universitas Sriwijaya, 2014. 